\title{
A mortality study among workers in an English asbestos factory
}

\author{
J. PETO, R. DOLL, S. V. HOWARD, L. J. KINLEN ${ }^{1}$, AND H. C. LEWINSOHN ${ }^{2}$ \\ From the DHSS Cancer Epidemiology and Clinical Trials Unit, Department of the Regius Professor of \\ Medicine, University of Oxford, and TBA Industrial Products Limited, Rochdale ${ }^{2}$
}

\begin{abstract}
The previous report on this cohort study of workers in an asbestos textile factory (Knox et al., 1968) showed little evidence of increased mortality among workers who had entered the factory after the implementation in 1932 of the first Asbestos Industry Regulations (1931) but observed that no firm conclusions could be drawn, as little carcinogenic effect would be expected for 20 years after first exposure. A further $8 \frac{1}{2}$ years of follow-up has revealed some asbestos-related disease in this latter group, although very much less than for employees first exposed before 1933. Among the 963 workers first exposed in 1933 or later, mortality was increased for carcinoma of the bronchus (31 deaths; $19 \cdot 3$ expected for all lung cancers) and non-malignant respiratory disease ( 35 deaths, $25 \cdot 0$ expected), and a further 5 deaths were attributed to pleural mesothelioma.
\end{abstract}

This cohort study of workers in an asbestos textile factory in the North of England has been the subject of three previous reports (Doll, 1955; Knox et al., 1965; Knox et al., 1968). These dealt particularly with mortality from lung cancer and respiratory disease in workers exposed to the high dust levels preceding the 1931 Asbestos Industry Regulations, and examined the dependence of lung cancer incidence on age and duration of exposure. The last report (Knox et al., 1968) showed little evidence of increased mortality among workers who had entered the factory after the implementation of the 1931 regulations in 1933 , but pointed out that no firm conclusions could be drawn because little carcinogenic effect would be expected for 20 years after first exposure. The present report is concerned particularly with the post-1932 population which, although exposed to dust levels which were higher than the present permitted levels, was employed during a time of improving dust control and plant modernisation.

\section{Methods}

This study is based on the 1106 men and women who by the end of 1972 had worked for over 10

\footnotetext{
${ }^{1}$ Gibb Fellow of the Cancer Research Campaign.

2Present address: Corporate Medical Director, Raybestos Manhatten, Trumbull, Connecticut, USA.

Received for publication 4 September 1976

Accepted for publication 3 December 1976
}

years in scheduled (dust risk) areas of the factory. The total population is divided into five cohorts on the basis of duration and period of work in scheduled areas (Table 1). A more detailed account of the cohorts and other aspects of the study is given in the previous report (Knox et al., 1968). Re-examination of personnel records since the last report showed that a further 23 workers were eligible for inclusion in cohorts 1 and 2; in addition 205 workers who have completed 10 years employment since June 1966 have been added to cohorts 3,4 and 5 . The study thus comprises 822 men and 284 women. This population was followed up to 31 December 1974 using factory personnel records and the National Health Service Central Register.

\section{Results}

Twenty-two $(2.0 \%)$ workers could not be traced and $13(1.2 \%)$ who are recorded in the NHS Central Register have emigrated or are not currently registered with a general practitioner. The remaining $1071(96.8 \%)$ have been followed up to the end of 1974. The numbers of deaths in each group attributed to lung cancer*, other cancers, respiratory diseases

* Deaths due to mesothelioma of the pleura are included under lung cancer. These are coded as benign (228, eighth revision of the International Classification of Diseases (World Health Organization, 1967), (8th ICD)) unless the word malignant or the site appears on the death certificate. 
Table 1 Number of workers in each exposure cohort

\begin{tabular}{|c|c|c|c|c|c|}
\hline Cohort & Sex & $\begin{array}{l}\text { Years in scheduled } \\
\text { areas }\end{array}$ & $\begin{array}{l}\text { Years in scheduled } \\
\text { areas before } 1933\end{array}$ & Number & $\begin{array}{l}\text { Person-years } \\
\text { observation }\end{array}$ \\
\hline $\begin{array}{l}1 \\
2 \\
3 \\
4 \\
5 \\
\text { Total }\end{array}$ & $\begin{array}{l}\text { Male } \\
\text { Male } \\
\text { Male } \\
\text { Male } \\
\text { Female }\end{array}$ & $\begin{array}{l}20 \text { or more } \\
20 \text { or more } \\
20 \text { or more } \\
10-19 \\
10 \text { or more }\end{array}$ & $\begin{array}{l}10 \text { or more } \\
\text { Less than } 10 \\
\text { None } \\
\text { None } \\
\text { None }\end{array}$ & $\begin{array}{c}69 \\
74 \\
263 \\
679^{*} \\
284 \\
1106\end{array}$ & $\begin{array}{r}1006 \\
1397 \\
2048 \\
7261 \\
4360 \\
16072\end{array}$ \\
\hline
\end{tabular}

*Including the 263 men in cohort 3 before they had completed 20 years in scheduled areas.

Table 2 Number of deaths observed and expected, by exposure cohort and cause

\begin{tabular}{|c|c|c|c|c|c|}
\hline Cause of death $\dagger$ & Cohort & Observed deaths $\ddagger$ & Expected deaths & $\begin{array}{l}\text { Ratio } \\
\text { observed/expected }\end{array}$ & $\begin{array}{l}\text { Probability of observed } \\
\text { number or more }\end{array}$ \\
\hline $\begin{array}{l}\text { Lung cancer and } \\
\text { pleural mesothelioma } \\
(162,163 \text { and } 228)\end{array}$ & $\begin{array}{l}1 \\
2 \\
3 \\
4 \\
5\end{array}$ & $\begin{array}{r}15(2) \\
10(3) \\
9(2) \\
24(2) \\
3(1)\end{array}$ & $\begin{array}{r}1.49 \\
3.05 \\
5.56 \\
12.82 \\
0.92\end{array}$ & $\begin{array}{r}10 \cdot 1 \\
3 \cdot 3 \\
1 \cdot 6 \\
1 \cdot 9 \\
3 \cdot 3\end{array}$ & $\begin{array}{r}<0.001 \\
0.001 \\
0.111 \\
0.003 \\
0.066\end{array}$ \\
\hline $\begin{array}{l}\text { Other cancers } \\
(140-239)\end{array}$ & $\begin{array}{l}1 \\
2 \\
3 \\
4 \\
5\end{array}$ & $\begin{array}{r}8 \\
3 \\
6 \\
11 \\
6\end{array}$ & $\begin{array}{r}4 \cdot 14 \\
4 \cdot 29 \\
6 \cdot 61 \\
17 \cdot 78 \\
7 \cdot 63\end{array}$ & $\begin{array}{l}1.9 \\
0.7 \\
0.9 \\
0.6 \\
0.8\end{array}$ & $\begin{array}{l}0.060 \\
0.801 \\
0.647 \\
0.966 \\
0.772\end{array}$ \\
\hline $\begin{array}{l}\text { Respiratory diseases } \\
(460-519)\end{array}$ & $\begin{array}{l}1 \\
2 \\
3 \\
4 \\
5\end{array}$ & $\begin{array}{r}14 \\
7 \\
8 \\
23 \\
4\end{array}$ & $\begin{array}{r}3 \cdot 86 \\
4 \cdot 32 \\
5 \cdot 93 \\
17 \cdot 28 \\
1 \cdot 81\end{array}$ & $\begin{array}{l}3.6 \\
1.6 \\
1.3 \\
1.3 \\
2.2\end{array}$ & $\begin{array}{r}<0.001 \\
0.147 \\
0.246 \\
0.108 \\
0.110\end{array}$ \\
\hline Other causes & $\begin{array}{l}1 \\
2 \\
3 \\
4 \\
5\end{array}$ & $\begin{array}{l}27 \\
23 \\
36 \\
69^{*} \\
11\end{array}$ & $\begin{array}{l}18 \cdot 29 \\
17 \cdot 89 \\
26 \cdot 57 \\
75 \cdot 06 \\
13 \cdot 34\end{array}$ & $\begin{array}{l}1.5 \\
1.3 \\
1.4 \\
0.9 \\
0.8\end{array}$ & $\begin{array}{l}0.033 \\
0.139 \\
0.047 \\
0.773 \\
0.776\end{array}$ \\
\hline All causes & $\begin{array}{l}1 \\
2 \\
3 \\
4 \\
5\end{array}$ & $\begin{array}{r}64 \\
43 \\
59 \\
127 \\
24\end{array}$ & $\begin{array}{r}27 \cdot 78 \\
29 \cdot 55 \\
44 \cdot 67 \\
122 \cdot 94 \\
23 \cdot 70\end{array}$ & $\begin{array}{l}2 \cdot 3 \\
1 \cdot 5 \\
1 \cdot 3 \\
1 \cdot 0 \\
1 \cdot 0\end{array}$ & $\begin{array}{r}<0.001 \\
0.012 \\
0.023 \\
0.369 \\
0.503\end{array}$ \\
\hline
\end{tabular}

+Coded according to the eighth revision of the International Classification of Diseases (World Health Organization, 1967).

$\ddagger$ Deaths due to pleural mesothelioma are included in the observed number for lung cancer and also given separately in parentheses.

*Includes one case in which a pleural mesothelioma was a contributory cause of death.

and other causes are compared in Table 2 with the numbers expected. These expected numbers were calculated in the usual way from national deathrates by five-year periods and five-year age-groups. To ensure that expected numbers are not underestimated, emigrants and those lost to follow-up were assumed to be alive on 31 December 1974. Deaths before 1 January 1931 or after the age of 85 are ignored, however, and expected numbers are calculated accordingly. Lung cancer mortality in Rochdale was lower than the national average among men (standardised mortality ratio (SMR) = 87) and similar for women (SMR = 104) in 1959-63 Registrar General, 1971).

Workers first exposed before 1933 (cohorts 1 and
2) suffered a marked excess of lung cancer and respiratory disease, particularly those with 10 or more years' exposure prior to 1933 . There is also some excess mortality from lung cancer and mesothelioma (36 observed, 19.3 expected; P§ $<0.001$ ) and respiratory disease ( 35 observed, 25.0 expected; $P=0.03)$ in those who entered scheduled areas after 1 January 1933 (cohorts 3, 4 and 5 combined), although the excess is very much less than in the first two cohorts. The slight excess of circulatory disease in cohort 3 reported at the previous follow-

§All significance levels give the probability of observing the actual number of deaths or more in a Poisson distribution with the expected mean. 
up (Knox et al., 1968) has not increased (27 observed, 20.64 expected; 9 observed, 4.03 expected in the 1968 report), while in cohorts 4 and 5 there was a matching deficit ( 50 observed, $60 \cdot 10$ expected). The inference that this was probably a chance observation thus seems confirmed. There were 16 deaths attributable to gastrointestinal cancers (151-154, 8th ICD) compared with 15.70 expected. No excess for any of these rubrics approached statistical significance in any cohort, and no peritoneal mesothelioma was reported.

To distinguish exposure immediately after 1933 from that under present conditions, cohorts 3,4 and 5 were divided into those first entering scheduled areas from 1933 to 1950 and those starting later. 1951 was taken as the start of the modern period because it was the year in which routine dust sampling was initiated, although it is known that dust levels in some areas remained high. Observed and expected deaths for those first exposed between 1933 and 1950 and those first exposed later are shown in Table 3. There is clear evidence of some excess of lung cancer and respiratory deaths among those first exposed between 1933 and 1950, although very much less than in cohorts 1 and 2 . There have been few deaths among those first exposed in 1951 or subsequently, but there still appears to be an excess of deaths from lung cancer 15 or more years after first exposure ( 5 observed, 1.86 expected: $(P=0.04)$. This is shown in Table 4 , in which deaths from lung cancer including pleural mesothelioma in these groups are distributed according to the time since first exposure; the relative risk increases progressively with time since first exposure in both groups.

The six employees first exposed after 1950 who died of lung cancer were all men and smokers; five worked in areas where dust levels were high in 1951 , and one may have been exposed to asbestos dust from 1925 to 1930 in a previous occupation. No case of mesothelioma has occurred in the population first exposed after 1950, although in view of the long latent period none would yet be expected (Newhouse and Berry, 1976). An approximately multiplicative effect of asbestos exposure and cigarette smoking on lung cancer incidence has been suggested (Doll, 1971; Berry et al., 1972), but without detailed smoking histories, which are being collected for the future, this cannot be quantified in this study. Asbestosis was found by the Pneumoconiosis Medical Board at post-mortem examination in three of the six cases. The numbers are too small for the magnitude of the excess of lung cancer in those first employed after 1950 to be estimated with any precision.

\section{DUST LEVELS}

The implementation of the Asbestos Industry Regulations (1931) started a drive to improve dust control interrupted only by the relaxation of

Table 3 Number of deaths observed and expected, by date of first exposure

\begin{tabular}{|c|c|c|c|c|c|}
\hline Cohort & Cause & Observed deaths $\ddagger$ & Expected deaths & $\begin{array}{l}\text { Ratio } \\
\text { observed/expected }\end{array}$ & $\begin{array}{l}\text { Probability of observed } \\
\text { number or more }\end{array}$ \\
\hline $\begin{array}{l}\text { Men and women first } \\
\text { exposed 1933-1950 } \\
(n=616)\end{array}$ & $\begin{array}{l}\text { Lung cancer } \\
\text { Other cancers } \\
\text { Respiratory } \\
\text { Other causes }\end{array}$ & $\begin{array}{c}30(5) \\
20 \\
33 \\
103 *\end{array}$ & $\begin{array}{l}16 \cdot 10 \\
27 \cdot 00 \\
21 \cdot 91 \\
97 \cdot 96\end{array}$ & $\begin{array}{l}1 \cdot 9 \\
0 \cdot 7 \\
1 \cdot 5 \\
1 \cdot 1\end{array}$ & $\begin{array}{l}0.001 \\
0.931 \\
0.016 \\
0.318\end{array}$ \\
\hline $\begin{array}{l}\text { Men and women first } \\
\text { exposed } 1951 \text { or later } \\
(n=347)\end{array}$ & $\begin{array}{l}\text { Lung cancer } \\
\text { Other cancers } \\
\text { Respiratory } \\
\text { Other causes }\end{array}$ & $\begin{array}{r}6(0) \\
3 \\
2 \\
13\end{array}$ & $\begin{array}{r}3 \cdot 20 \\
5 \cdot 02 \\
3 \cdot 11 \\
17 \cdot 01\end{array}$ & $\begin{array}{l}1.9 \\
0.6 \\
0.6 \\
0.8\end{array}$ & $\begin{array}{l}0 \cdot 105 \\
0.877 \\
0 \cdot 817 \\
0.865\end{array}$ \\
\hline
\end{tabular}

¥Deaths due to pleural mesothelioma are included in the observed number for lung cancer and also given separately in parentheses. Includes one case in which a pleural mesothelioma was a contributory cause of death.

Table 4 Observed and expected deaths from lung cancer by date of first exposure and time since first exposure

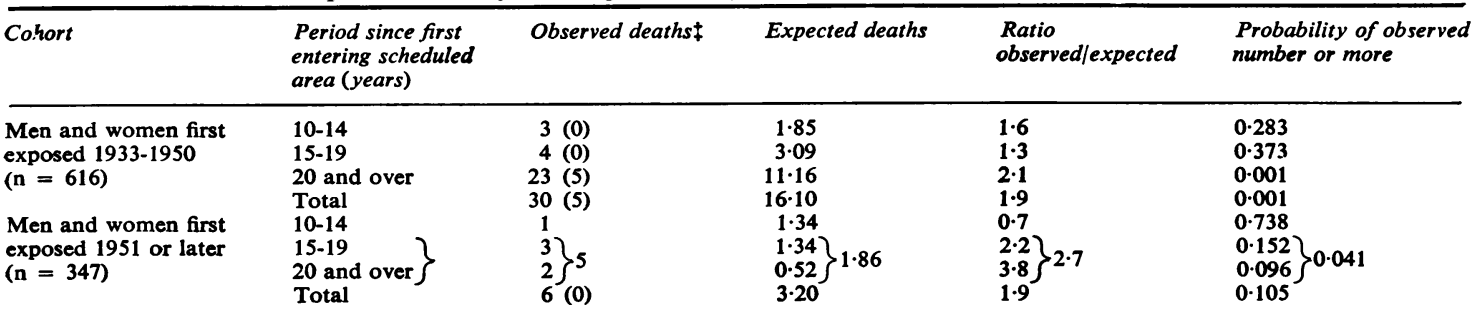

$\ddagger$ Deaths from pleural mesothelioma are included in the observed number for lung cancer and also given separately in parentheses. 
Table 5 Dust levels accompanying different textile processes, 1952-1974

\begin{tabular}{|c|c|c|c|c|c|c|}
\hline \multirow[t]{3}{*}{ Department } & \multirow[t]{3}{*}{ Process } & \multicolumn{5}{|c|}{ Yearly mean dust levels } \\
\hline & & \multicolumn{2}{|c|}{$\begin{array}{l}\text { Casella thermal precipitator } \\
\text { (particles per cc) }\end{array}$} & \multicolumn{3}{|c|}{$\begin{array}{l}\text { Long running thermal precipitator or } \\
\text { cellulose membrane (fibres per cc) }\end{array}$} \\
\hline & & 1952 & 1960 & 1961 & 1966 & 1974 \\
\hline \multirow[t]{3}{*}{ Fiberising } & $\begin{array}{l}\text { Mixing } \\
\text { Opening }\end{array}$ & $\begin{array}{l}500 \\
440\end{array}$ & - & - total & $\overline{\operatorname{sed}}$ & - \\
\hline & Bag slitting & - & 110 & 5 & 4 & 2 \\
\hline & Mechanical bagging & - & 120 & 4 & 5 & 3 \\
\hline \multirow[t]{4}{*}{ Carding } & Fine cards & 200 & 200 & 6 & 6 & 3 \\
\hline & Medium cards & 810 & 400 & 8 & 8 & 3 \\
\hline & Coarse cards & 1140 & 420 & 7 & 8 & 4 \\
\hline & Electrical sliver cards & 490 & 260 & 5 & 2 & 2 \\
\hline \multirow[t]{3}{*}{ Spinning } & Fine spinning & 170 & 110 & 4 & 3 & 1 \\
\hline & Roving frames & 510 & 150 & 5 & 6 & 3 \\
\hline & Intermediate frames & 530 & 100 & 5 & 6 & 4 \\
\hline \multirow[t]{4}{*}{ Weaving } & Beaming & 190 & 220 & 8 & 4 & $<1$ \\
\hline & Pirn winding & 350 & 130 & 3 & 3 & $<1$ \\
\hline & Cloth weaving & 180 & 140 & 3 & 2 & $<1$ \\
\hline & Listing weaving & 130 & 110 & 2 & 1 & $<1$ \\
\hline Plaiting & Plaiting & 140 & 80 & 4 & 4 & 3 \\
\hline
\end{tabular}

Table 6 Mean dust levels and number of men exposed to them in selected years from 1936-1972 (BOHS data)

\begin{tabular}{|c|c|c|c|c|c|}
\hline \multirow[t]{2}{*}{ Year } & \multirow{2}{*}{$\begin{array}{l}\text { Mean dust level } \\
\text { (fibres per } c c \text { ) }\end{array}$} & \multirow[t]{2}{*}{ Number of men } & \multicolumn{3}{|c|}{ Percentage exposed at various levels } \\
\hline & & & $f \leqslant 2$ & $2<f \leqslant 5$ & $f>5$ \\
\hline 1936 & $13 \cdot 3$ & 15 & 0 & 0 & 100 \\
\hline 1941 & 14.5 & 49 & 4 & 0 & 96 \\
\hline 1946 & $13 \cdot 2$ & 87 & 2 & 2 & 96 \\
\hline 1951 & $10 \cdot 8$ & 189 & 2 & 9 & 89 \\
\hline 1952 & 10.9 & 219 & 2 & 9 & 89 \\
\hline 1956 & $5 \cdot 3$ & 294 & 2 & 40 & 58 \\
\hline 1960 & $5 \cdot 4$ & 349 & 6 & 31 & 63 \\
\hline 1961 & 52 & 351 & 6 & 35 & 59 \\
\hline 1966 & $5 \cdot 4$ & 359 & 23 & 22 & 55 \\
\hline 1971 & 3.4 & 258 & 32 & 43 & 25 \\
\hline 1972 & 2.9 & 233 & 32 & 65 & 3 \\
\hline
\end{tabular}

$f=$ fibres per cc.

regulations during the second world war, when working hours were increased and blackout restrictions interfered with ventilation. Technical improvements since 1933 included major changes between 1953 and 1957, and dust levels have fallen by approximately $50-80 \%$ throughout the factory over the last 25 years, the largest reductions being in areas where levels were highest in 1961 (Table 5). Data on numbers of employees and dust levels in different areas of the factory submitted by the company to the British Occupational Hygiene Society (BOHS) Subcommittee on Asbestos have also been made available to us (Table 6). Routine dust measurements were not made prior to 1951, but it is estimated that levels in 1933 were at least 1.5 times the average between 1951 and 1955, and the estimates in Table 6 are based on this figure. It was assumed that levels remained constant from 1933 to 1945 and then fell steadily between 1945 and 1950 . Mean dust levels were weighted by the number of men exposed at each level, so that the apparent increase between 1936 and 1941 reflects a fall in the proportion of employees working in low dust areas rather than a general increase in estimated dust levels. The estimates in Table 6 are based on 379 men with no exposure before 1933, still employed at some time between 1966 and 1972, who had worked for at least 10 years in scheduled areas. All dust levels have been estimated from fixed sampling points.

It is apparent from these estimates that the mean dust level has been below five fibres/cc only in the last decade. In 1951 the mean dust level was $10 \cdot 8$ fibres/cc, and $89 \%$ of the men in the BOHS series were exposed to mean levels greater than 5 fibres/cc in that year. By 1972 the mean was 2.9 fibres/cc, and only $3 \%$ were exposed to a mean level greater than 5 fibres/cc, $65 \%$ to a mean level between $2-5$ fibres/cc and $32 \%$ to a mean level below 2 fibres/cc (Table 6). 


\section{Discussion}

It is difficult to interpret the relevance of these results to modern conditions. The object of this study was to establish the value of technical improvements since 1931, but as there is a delay of 15 or more years between first exposure and any resulting cancer our results do not reflect the effects of working conditions over the last 15 or 20 years. We therefore propose to continue follow-up on those entering scheduled areas since 1951, and subsequent analysis will focus on the relationship between mortality and dust levels at first exposure. Such estimates will contribute to the establishment of hygiene standards designed to minimise asbestosis and lung cancer.

We would like to thank the Office of Population Censuses and Surveys, including the National Health Service Central Register, the British Occupational Hygiene Society Subcommittee on Asbestos, and many individuals at TBA Industrial Products Limited, particularly Dr S. Holmes and Mr I. Waters, for their co-operation.

\section{References}

Asbestos Industry Regulations (1931). Asbestos Industry Regulations: Statutory Rules and Orders, 1931, No. 1140. HMSO: London.

Berry, G., Newhouse, M. L., and Turok, M. (1972). Combined effects of asbestos exposure and smoking on mortality from lung cancer in factory workers. Lancet, 2 , 476-479.

Doll, R. (1955). Mortality from lung cancer in asbestos workers. British Journal of Industrial Medicine, 12, 81-86.

Doll, R. (1971). The age distribution of cancer: implications for models of carcinogenesis. Journal of the Royal Statistical Society A, 134, 133-166.

Knox, J. F., Doll, R. S., and Hill, I. D. (1965). Cohort analysis of changes in incidence of bronchial carcinoma in a textile asbestos factory. Annals of the New York Academy of Sciences, 132, 526-535.

Knox, J. F., Holmes, S., Doll, R., and Hill, I. D. (1968). Mortality from lung cancer and other causes among workers in an asbestos textile factory. British Journal of Industrial Medicine, 25, 293-303.

Newhouse, M. L., and Berry, G. (1976). Predictions of mortality from mesothelial tumours in asbestos factory workers. British Journal of Industrial Medicine, 33, 147-151.

Registrar General (1971). Registrar General's Decennial Supplement: England and Wales Area Mortality Tables for 1961. HMSO: London.

World Health Organization (1967). International Classification of Diseases. WHO: Geneva. 